J. M. Dalziel, produced The Flora of West Tropical Africa, a two-volume work describing the 6,000 species then known for a vast area of western Africa. This flora set new standards, being based mainly on a system of keys rather than formal descriptions, and served as a model of conciseness for a number of subsequent floras.

Many people owe their interest in plants or botany to Hutchinson. $\mathrm{He}$ was adept at popularization, writing easily and clearly, and having the unusual gift of being able to illustrate his own works. In 1945 his little book, Common Wild Flowers, was published in the Penguin series, and further volumes, More Common Wild Fowers and Uncommon Wild Flowers, followed in 1948 and 1950 . In 1948 he published (with Dr R. Melville) The Story of Plants.

His skill as an artist has already been mentioned. Most of his work was in black-and-white, executed fluently, accurately and with considerable artistic merit. Some of his artistic work has been exhibited internationally.

Deservedly, many honours were bestowed on him, including an honorary Doctorate of Laws at the University of St Andrews in 1934, Fellowship of the Royal Society in 1947, the Victoria Medal of Honour of the Royal Horticultural Society, and the Linnean Gold Medal of the Linnean Society of London in 1965. This year his eminence was recognized by the award of the OBE.

In assessing his achievements various points stand out: firstly, his extraordinary productivity; his major works alone cover more than 6,000 pages of print. Next, perhaps, is the way in which he continued to work after retirement in 1948. Probably the major part of his published work dates from after that time. Indeed, on the very day of his death he worked in the Kew herbarium which had for so many years been his working home.

In spite of his activity he always had time to talk to and encourage younger people. His kindliness to others and his innocent and endearing delight in his own achievements will not easily be forgotten by those privileged to know him.

\section{Academician P. A. Rehbinder}

THE recent death of Academician Rehbinder, the Soviet Union's most eminent colloid scientist, will be sad news for those who had the privilege of meeting him. He died at the age of 74 , following a heart attack, while still at the height of his intellectual powers, having led his country's research in disperse systems for nearly 50 years. Over this period he published, with a long series of colleagues, about 500 scientific papers, and his students included some 30 full "doctorates" and 100 "candidates" (comparable with PhD).

Academic Rehbinder was an early pioneer in the fundamental study of the flotation of minerals-but he is nowadays best known for the "Rehbinder Effect" and for systematic studies of the rheological properties of disperse systems. The Rehbinder Effect is the reduction of strength of solids by the action of surface-active substances. Originally this effect was interpreted simply as a lowering of surface energy by adsorption and hence reduction of the work required to produce new interface; but it must also involve the creep- age of surfactant down grain boundaries or dislocations while the body is under stress. Examples of the effect are claimed to occur with materials as diverse as pure metals and various types of rock (under the action of rock drills, or during crushing and grinding).

Rehbinder's researches in recent years were particularly directed to studies of the "physico-chemical mechanics" of dispersions of practical interest such as clay slurries and cement pastes, for which purpose a range of measuring instruments was developed. Other interests included adhesives, emulsions and foams. This work was carried out partly in the Department of Colloid Chemistry in the University of Moscow, where Rehbinder was professor (and, it is said, a brilliant teacher), and partly in the section of Disperse Systems at the Institute of Physical Chemistry of the Academy of Sciences of the USSR - a section which he headed from its formation to the time of his death.

Academician Rehbinder was an indefatigable worker for colloid science, including amongst his activities the work of Editor-in-Chief of the Kolloidnyi Zhurnal. He was also the Soviet Union's representative on the scientific committee for the International Congress of Surface Active Substances. At the same time, he was a man of exceptionally wide cultural interests-a connoisseur of art, literature and music, and a fluent linguist in both French and German. No note of his life would ring true without a tribute to his personal charm, his encouragement for younger colleagues, and his earnest concern to develop friendly personal contacts with foreign fellowscientists who visited Moscow or whom he met at congresses.

\section{HOW TO BUY NATURE}

Volumes start in January, March, May, July, September and November, but subscriptions may begin at any time. The direct postal price per subscription is:

12 MONTHS (52 issues per title)

$\begin{array}{lcc} & \begin{array}{c}\text { Surface mail } \\ \text { UK and } \\ \text { worldwide }\end{array} & \begin{array}{c}\text { U.S.A. and } \\ \text { Canada }\end{array} \\ \begin{array}{l}\text { Nature (Friday) } \\ \begin{array}{l}\text { Nature + } \\ \text { Nature Physical Science }\end{array}\end{array} & £ 24 & \$ 48 \\ \begin{array}{l}\text { Nature + } \\ \text { Nature New Biology }\end{array} & £ 24 & \$ 83 \\ \text { All three editions } & £ 29.50 & \$ 108 \\ \text { Annual Index } & £ 1 & \$ 3\end{array}$

(Charge for delivery by air mail on application)
Editorial, Advertising and Publishing Offices of NATURE

MACMILLAN JOURNALS LIMITED

4 LITTLE ESSEX STREET, LONDON WC2R 3LF

Telephone Number: 01-836 6633. Telegrams: Phusis London WC2R 3LF Telex 262024

MACMILLAN JOURNALS LIMITED

711 NATIONAL PRESS BUILDING WASHINGTON DC 20004

Telephone Number: 202-737 2355. Telex 64280

International Advertisement Manager PETER R, KAVANAGH

MACMILLAN JOURNALS LIMITED

4 LITTLE ESSEX STREET, LONDON WC2R 3LF

Telephone Numbers: UK 01-836 6633. USA 202-737 2355

Subscription Department

MACMILLAN JOURNALS LIMITED

BRUNEL ROAD, BASINGSTOKE, HANTS

Telephone Number: Basingstoke 29242

Classified advertisements

T. G SCOTT \& SON, LIMITED

1 CLEMENT'S INN, LONDON WC2A 2ED

Telephone Number: 01-242 6264/01-405 4743

Telegrams: Textualist London WC2A 2ED

Registered as a newspaper at the Post Office

Copyright (C) Macmillan Journals Limited, December 81972 